\title{
T-cell senescence contributes to abnormal glucose homeostasis in humans and mice
}

\author{
Hyon-Seung $\mathrm{Yi}^{1,2}$, So Yeon Kim³,4, Jung Tae Kim ${ }^{1,5}$, Young-Sun Lee ${ }^{6}{ }^{6}$, Ji Sun Moon ${ }^{1}$, Mingyo Kim7, Yea Eun Kang ${ }^{1,2}$,
} Kyong Hye Joung ${ }^{1,2}$, Ju Hee Lee ${ }^{1,2}$, Hyun Jin Kim,2, Kwangsik Chun ${ }^{8}$, Minho Shong ${ }^{1,2}$ and Bon Jeong Ku ${ }^{1,2}$

\begin{abstract}
Chronic inflammation is a driving force for the development of metabolic disease including diabetes and obesity. However, the functional characteristics of T-cell senescence in the abnormal glucose homeostasis are not fully understood. We studied the patients visiting a hospital for routine health check-ups, who were divided into two groups: normal controls and people with prediabetes. Gene expression profiling of peripheral blood mononuclear cells from normal controls and patients with type 2 diabetes was undertaken using microarray analysis. We also investigated the immunometabolic characteristics of peripheral and hepatic senescent $T$ cells in the normal subjects and patients with prediabetes. Moreover, murine senescent T cells were tested functionally in the liver of normal or mice with metabolic deterioration caused by diet-induced obesity. Human senescent $\left(\mathrm{CD} 28^{-} \mathrm{CD} 57^{+}\right) \mathrm{CD} 8^{+} \mathrm{T}$ cells are increased in the development of diabetes and proinflammatory cytokines and cytotoxic molecules are highly expressed in senescent T cells from patients with prediabetes. Moreover, we demonstrate that patients with prediabetes have higher concentrations of reactive oxygen species (ROS) in their senescent $C D 8^{+} \mathrm{T}$ cells via enhancing capacity to use glycolysis. These functional properties of senescent $C D 8^{+} T$ cells contribute to the impairment of hepatic insulin sensitivity in humans. Furthermore, we found an increase of hepatic senescent T cells in mouse models of aging and diet-induced obesity. Adoptive transfer of senescent $\mathrm{CD} 8^{+} \mathrm{T}$ cells also led to a significant deterioration in systemic abnormal glucose homeostasis, which is improved by ROS scavengers in mice. This study defines a new clinically relevant concept of T-cell senescence-mediated inflammatory responses in the pathophysiology of abnormal glucose homeostasis. We also found that T-cell senescence is associated with systemic inflammation and alters hepatic glucose homeostasis. The rational modulation of T-cell senescence would be a promising avenue for the treatment or prevention of diabetes.
\end{abstract}

\section{Introduction}

Chronic inflammation is strongly associated with metabolic diseases, including diabetes and atherosclerosis ${ }^{1,2}$. Patients with insulin resistance are considered to be at

\footnotetext{
Correspondence: Hyon-Seung Yi (jmpbooks@cnu.ac.kr) or Bon

Jeong Ku (bonjeong@cnu.ac.kr)

'Research Center for Endocrine and Metabolic Diseases, Chungnam National University Hospital, Chungnam National University School of Medicine, Daejeon 35015, Republic of Korea

${ }^{2}$ Department of Internal Medicine, Chungnam National University School of Medicine, Daejeon 35015, Republic of Korea

Full list of author information is available at the end of the article. These authors contributed equally: Hyon-Seung Yi and So Yeon Kim Edited by T. Kaufmann
}

greater risk of cardiovascular disease ${ }^{3}$. Proinflammatory cytokines, such as tumor necrosis factor- $\alpha$ (TNF- $\alpha$ ), interleukin (IL)-1 $\beta$, and IL-6, play essential roles in the pathogenesis of insulin resistance ${ }^{4,5}$. Moreover, patients with prediabetes show significantly lower insulin sensitivity and higher levels of inflammatory markers than metabolically normal individuals ${ }^{6}$. In addition, low-grade inflammation in prediabetes is thought to increase the risk of a cardiovascular event ${ }^{7}$.

Aging of the immune system also contributes to the development of chronic inflammation and has an important effect on metabolic disease and immunologic disorders in humans ${ }^{8}$. In addition, low-grade chronic

\section{(c) The Author(s) 2019}

(c) (i) Open Access This article is licensed under a Creative Commons Attribution 4.0 International License, which permits use, sharing, adaptation, distribution and reproduction c. in any medium or format, as long as you give appropriate credit to the original author(s) and the source, provide a link to the Creative Commons license, and indicate if changes were made. The images or other third party material in this article are included in the article's Creative Commons license, unless indicated otherwise in a credit line to the material. If material is not included in the article's Creative Commons license and your intended use is not permitted by statutory regulation or exceeds the permitted use, you will need to obtain permission directly from the copyright holder. To view a copy of this license, visit http://creativecommons.org/licenses/by/4.0/. 


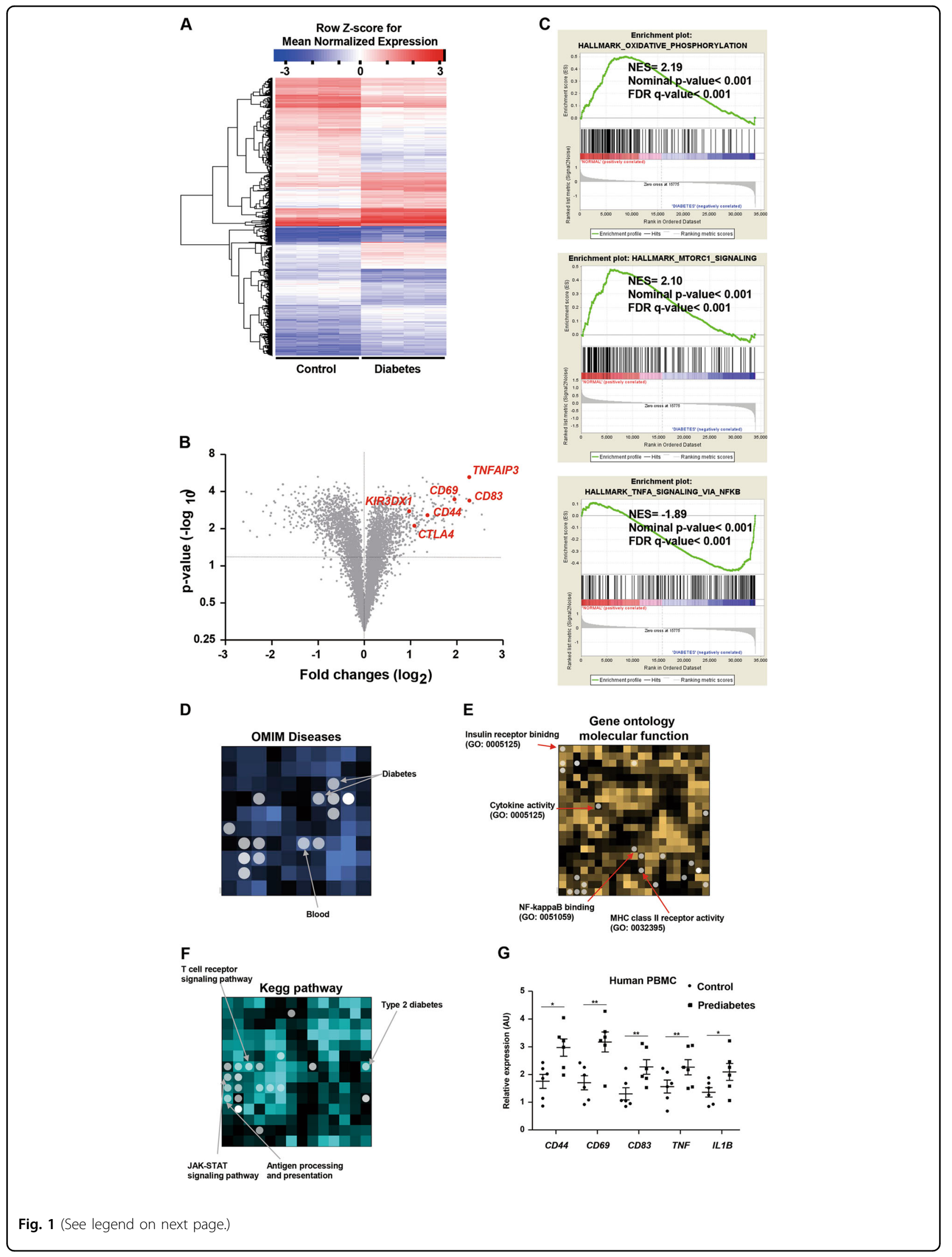


(see figure on previous page)

Fig. 1 Identification of differentially expressed genes in PBMCs from normoglycemic controls and patients with prediabetes. a Hierarchical clustering and heatmap based on genes that were differentially expressed in PBMCs from patients with prediabetes $(n=4)(\geq 2$-fold change in expression compared with normoglycemic controls $(n=4))$. $\mathbf{b}$ Volcano plot based on the differential expression and significance of the differences in 44,547 Agilent gene probes. Red dots represent genes associated with T-cell activation and inflammation with $P<0.05$ and fold change $>1$ log2. c The diagram shows the result of Gene Set Enrichment Analysis, including the enrichment scores. $\mathbf{d}$-f The analysis was performed using Network2Canvas. Genes that were significantly upregulated in the PBMCs of normal controls and patients with prediabetes were analyzed for genelist enrichment with gene set libraries created from level 4 of the MGI mouse phenotype ontology using Network2Canvas. g PBMCs isolated from controls $(n=6)$ and patients $(n=6)$ with prediabetes were subjected to real-time PCR. Data are expressed as mean \pm SEM. ${ }^{*} P<0.05$ and ${ }^{* *} P<0.01$ compared with the corresponding controls

inflammation is a driver of immunosenescence ${ }^{9}$. The chronic inflammatory environment that is a characteristic of metabolic diseases may also be induced by augmented secretion of proinflammatory cytokines, including TNF- $\alpha$ and IL-6, reactive oxygen species (ROS), and acute-phase reactants released from senescent immune cells. In human studies, several lines of evidence indicate that a senescent $\mathrm{T}$-cell-mediated inflammatory response is associated with the pathogenesis of acute coronary syndrome and hypertension ${ }^{10,11}$. However, any relationship between the immunosenescence of $\mathrm{T}$ cells and abnormal glucose homeostasis remains to be elucidated.

The loss of the co-stimulatory molecule CD28 and the gain of CD57 expression are prominent markers of the aging immune system in human $\mathrm{CD} 4^{+}$or $\mathrm{CD} 8^{+} \mathrm{T}$ cells ${ }^{12,13}$. CD28 is downregulated after replicative senescence ${ }^{14}$, but loss or gain of CD28 is also associated with proinflammatory conditions and diseases ${ }^{4,10,15-18}$. These $\mathrm{CD} 28^{-} \mathrm{T}$ cells, which have shortened telomeres, show reductions in T-cell receptor diversity and cytotoxic capacity ${ }^{12}$. CD $57^{+} \mathrm{T}$ cells are proliferation incompetent in response to antigen-specific stimulation and susceptible to apoptosis upon T-cell activation $^{19,20}$. Although these senescent $\mathrm{T}$ cells might contribute to the pathogenesis of immune disorders, the role of senescent $\mathrm{T}$ cells in metabolic diseases has yet to be determined.

In the present study, we investigate whether $\mathrm{T}$-cell senescence contributes to the systemic inflammatory response in patients with prediabetes and mice with dietinduced obesity by immunologically characterizing senescent $\mathrm{T}$ cells. We also demonstrate that the presence of these senescent $\mathrm{T}$ cells is associated with hepatic inflammation and impaired glucose homeostasis in mice and humans. In summary, this study suggests the existence of an immunometabolic link between T-cell senescence and the pathophysiology of diabetes.

\section{Results}

\section{Patients with type 2 diabetes exhibit systemic} proinflammatory response

We compared dendrograms and cluster heatmap visualizations created using our heuristics with the default heuristic in $\mathrm{R}$ and seriation-based leaf ordering methods (Fig. 1a). The expression of 1324 genes differed between peripheral blood mononuclear cells (PBMCs) from drugnaive patients with type 2 diabetes and those from controls (Fig. 1a). We then found that the 10 representative terms Gene Ontology Biological Process and Cellular Component and Molecular Function were enriched in PBMCs from drug-naive patients with type 2 diabetes (Supplementary Fig. 1a-c). Interestingly, genes associated with the immune response, the defense response and the inflammatory response were enriched in PBMCs from the patients with type 2 diabetes (Fig. 1b). Consistent with this, gene set enrichment analysis revealed a strong correlation of genes upregulated in PBMCs from drug-naive patients with type 2 diabetes with a gene set that identifies TNF- $\alpha$ signaling via nuclear factor kappa B (Fig. 1c). Conversely, a gene set involved in oxidative phosphorylation and mTORC1 signaling was enriched in normal controls compared with patients with diabetes (Fig. 1c). Furthermore, enrichment analysis with Network2Canvas revealed differing expression of signaling molecules implicated in diabetes and the immune system between the two groups (Fig. 1d-f and Supplementary Fig. 1d).

\section{Prediabetes is associated with increased inflammation in humans}

Patients with prediabetes also exhibit higher levels of inflammatory markers and are more susceptible to cardiovascular diseases ${ }^{21}$. However, it remains unclear what kind of immune cells contribute to the development of prediabetes. Thus, the study for the immune cells in patients with prediabetes possibly contributes to elucidating pathogenesis of overt diabetes. In this study, the 80 participants included in the final analysis were classified into two groups: normal controls and patients with prediabetes. The demographics and baseline characteristics of both the patients with prediabetes and the control subjects with normal glucose tolerance are summarized in Table 1. The expression of genes involved in human Tcell activation, including CD44 and CD69, as well as proinflammatory cytokines, was significantly higher in patients with prediabetes (Fig. 1g). As shown in 
Table 1 Demographics and baseline characteristics of both patients with prediabetes and normoglycemic control subjects

\begin{tabular}{|c|c|c|c|}
\hline Variables & $\begin{array}{l}\text { Control } \\
(n=40)\end{array}$ & $\begin{array}{l}\text { Prediabetes } \\
(n=40)\end{array}$ & $P$ value \\
\hline Age, y & $51.4 \pm 12.1$ & $54.8 \pm 9.7$ & 0.11 \\
\hline Male, $n(\%)$ & $12(30.0 \%)$ & $12(30.0 \%)$ & $\ldots$ \\
\hline Height, cm & $159.6 \pm 7.3$ & $159.1 \pm 6.5$ & 0.374 \\
\hline Weight, kg & $59.4 \pm 11.7$ & $62.7 \pm 11.1$ & 0.134 \\
\hline $\mathrm{BMI}, \mathrm{kg} / \mathrm{m}^{2}$ & $23.3 \pm 3.5$ & $24.6 \pm 3.9$ & 0.074 \\
\hline Current smoking, $n$ (\%) & $3(7.50 \%)$ & $3(7.50 \%)$ & $\cdots$ \\
\hline $\mathrm{SBP}, \mathrm{mm} \mathrm{Hg}$ & $123.3 \pm 15.3$ & $126.7 \pm 13.8$ & 0.279 \\
\hline $\mathrm{DBP}, \mathrm{mm} \mathrm{Hg}$ & $75.9 \pm 11.1$ & $76.6 \pm 9.0$ & 0.468 \\
\hline Hemoglobin, g/dL & $13.3 \pm 0.7$ & $13.3 \pm 1.1$ & 0.143 \\
\hline $\mathrm{HbA} 1 \mathrm{c}, \%$ & $5.3 \pm 0.2$ & $5.9 \pm 0.3$ & $<0.001$ \\
\hline $\mathrm{FBG}, \mathrm{mg} / \mathrm{dL}$ & $91.0 \pm 5.6$ & $100.2 \pm 5.4$ & $<0.001$ \\
\hline $\mathrm{PP} 2, \mathrm{mg} / \mathrm{dL}$ & $100.1 \pm 20.4$ & $148.5 \pm 28.3$ & 0.002 \\
\hline Fasting insulin, $\mu \mathrm{lU} / \mathrm{mL}$ & $8.0 \pm 3.1$ & $9.5 \pm 6.5$ & 0.25 \\
\hline PP2 insulin, $\mu \mathrm{lU} / \mathrm{mL}$ & $31.1 \pm 23.4$ & $59.7 \pm 62.6$ & 0.045 \\
\hline $\begin{array}{l}\text { Fasting c-peptide, pmol/ } \\
\mathrm{mL}\end{array}$ & $0.6 \pm 0.4$ & $0.7 \pm 0.5$ & 0.284 \\
\hline PP2 c-peptide, pmol/mL & $2.6 \pm 1.4$ & $3.3 \pm 1.7$ & 0.073 \\
\hline HOMA-IR & $1.8 \pm 0.8$ & $2.4 \pm 1.7$ & 0.127 \\
\hline Insulin (PP2/fasting) & $3.6 \pm 1.7$ & $5.6 \pm 3.2$ & 0.009 \\
\hline c-peptide (PP2/fasting) & $4.2 \pm 1.3$ & $5.0 \pm 1.7$ & 0.048 \\
\hline Total cholesterol, mg/dL & $187.0 \pm 36.8$ & $197.3 \pm 42.1$ & 0.225 \\
\hline Triglyceride, mg/dL & $123.0 \pm 35.4$ & $122.5 \pm 36.6$ & 0.352 \\
\hline $\mathrm{HDL}-\mathrm{C}, \mathrm{mg} / \mathrm{dL}$ & $64.5 \pm 16.5$ & $55.1 \pm 12.7$ & 0.022 \\
\hline $\mathrm{LDL}-\mathrm{C}, \mathrm{mg} / \mathrm{dL}$ & $81.2 \pm 57.3$ & $137.8 \pm 80.9$ & 0.003 \\
\hline $\begin{array}{l}\text { Aspartate transaminase, } \\
\text { IU/L }\end{array}$ & $23.4 \pm 20.9$ & $23.3 \pm 14.8$ & 0.474 \\
\hline $\begin{array}{l}\text { Alanine transaminase, IU/ } \\
\mathrm{L}\end{array}$ & $24.7 \pm 32.4$ & $25.4 \pm 24.8$ & 0.484 \\
\hline Creatinine, mg/dL & $0.7 \pm 0.1$ & $0.7 \pm 0.1$ & 0.423 \\
\hline $\mathrm{hsCRP}, \mathrm{mg} / \mathrm{dL}$ & $0.9 \pm 0.8$ & $1.5 \pm 2.0$ & 0.085 \\
\hline
\end{tabular}

$B M I$ body mass index $S B P$, systolic blood pressure, $D B P$ diastolic blood pressure, $H b A 1 c$ glycated hemoglobin, FBG fasting blood glucose, PP2 post-prandial $2 \mathrm{~h}$ blood glucose, HOMA-IR homeostasis model assessment-estimated insulin resistance, $H D L-C$ high-density lipoprotein cholesterol, $L D L-C$ low-density lipoprotein cholesterol, $h s C R P$ high-sensitivity C-reactive protein

Supplementary Fig. 2, the patients with prediabetes showed higher serum levels of TNF- $\alpha$ than controls with normoglycemia. Serum IFN- $\gamma$ and IL-1 $\beta$ also showed a tendency toward increase in the patients with prediabetes compared with normal controls (Supplementary Fig. 2a-c). These findings suggest that prediabetes is associated with systemic proinflammatory response.

\section{Senescent $\mathrm{CD}^{+} \mathrm{T}$ cells are more numerous in patients with prediabetes in humans}

Next, we investigated the immunophenotype of T cells in PBMCs from normal controls and patients with prediabetes. PBMCs were first gated for single cells (forward scatter-area vs. forward scatter-height) and lymphocytes (forward scatter-area vs. side scatter-area). The lymphocyte population was then further analyzed for uptake of a fixable viability dye to determine the proportion of live cells, and stained for CD3. The surface expression of CD4 and CD8 was then determined in this gated population (Fig. 2a). To compare the immunosenescence of $\mathrm{T}$ cells in PBMCs from normal controls and patients with prediabetes, we evaluated the frequency of $\mathrm{CD}^{+} 7^{+}$and/or $\mathrm{CD} 28^{-} \mathrm{T}$ cells among the $\mathrm{CD} 4^{+}$and $\mathrm{CD} 8^{+} \mathrm{T}$ cells in the PBMCs from the study population. Among $\mathrm{CD} 4^{+} \mathrm{T}$ cells, the $\mathrm{CD} 28^{-} \mathrm{CD} 57^{+}$senescent population tended to be larger in patients with prediabetes, but this difference did not reach statistical significance (Fig. 2b). The population of $\mathrm{CD} 28^{-} \mathrm{CD} 57^{+} \mathrm{CD} 8^{+} \mathrm{T}$ cells was also significantly larger in patients with prediabetes (Fig. 2c). We also analyzed the population of $\mathrm{CD} 28^{-} \mathrm{CD} 57^{+}$senescent $\mathrm{CD} 4^{+}$and $\mathrm{CD}^{+} \mathrm{T}$ cells in the patients with prediabetes according to diagnostic criteria for prediabetes. There was no significant difference in the population of $\mathrm{CD} 28^{-} \mathrm{CD} 57^{+} \mathrm{CD} 4^{+} \mathrm{T}$ cells among groups of subjects with impaired fasting glucose (IFG), impaired glucose tolerance (IGT), and IFG plus IGT (Supplementary Fig. 3a). However, the population of $\mathrm{CD} 28^{-} \mathrm{CD} 57^{+} \mathrm{CD} 8^{+}$ $\mathrm{T}$ cells was significantly larger in patients with IFG plus IGT than in patients with IFG alone (Supplementary Fig. 3b). Collectively, these data demonstrate that there are more immunosenescent $\mathrm{CD} 8^{+} \mathrm{T}$ cells in patients with prediabetes than in normoglycemic subjects.

\section{Proinflammatory cytokines and cytotoxic molecules are highly expressed in senescent $T$ cells from patients with prediabetes}

Senescent $T$ cells have the ability to secret a large quantity of proinflammatory cytokines and cytotoxic molecules $^{22}$. Therefore, we investigated the functional characteristics of senescent $\mathrm{CD} 4^{+}$and $\mathrm{CD} 8^{+} \mathrm{T}$ cells from normal controls and patients with prediabetes. IFN $-\gamma$, TNF- $\alpha$, and IL-17A production was quantified in the senescent $\mathrm{CD}^{+}$and $\mathrm{CD}^{+} \mathrm{T}$ cells. In consistent with previous reports ${ }^{23,24}$, IFN- $\gamma$ and TNF- $\alpha$ production in total $\mathrm{CD}^{+}$and $\mathrm{CD}^{+} \mathrm{T}$ cells were increased in patients with prediabetes (Fig. 3a-d). As shown in Supplementary Fig. $4 \mathrm{a}-\mathrm{d}$, the population of IFN- $\gamma$ and TNF- $\alpha$ producing 


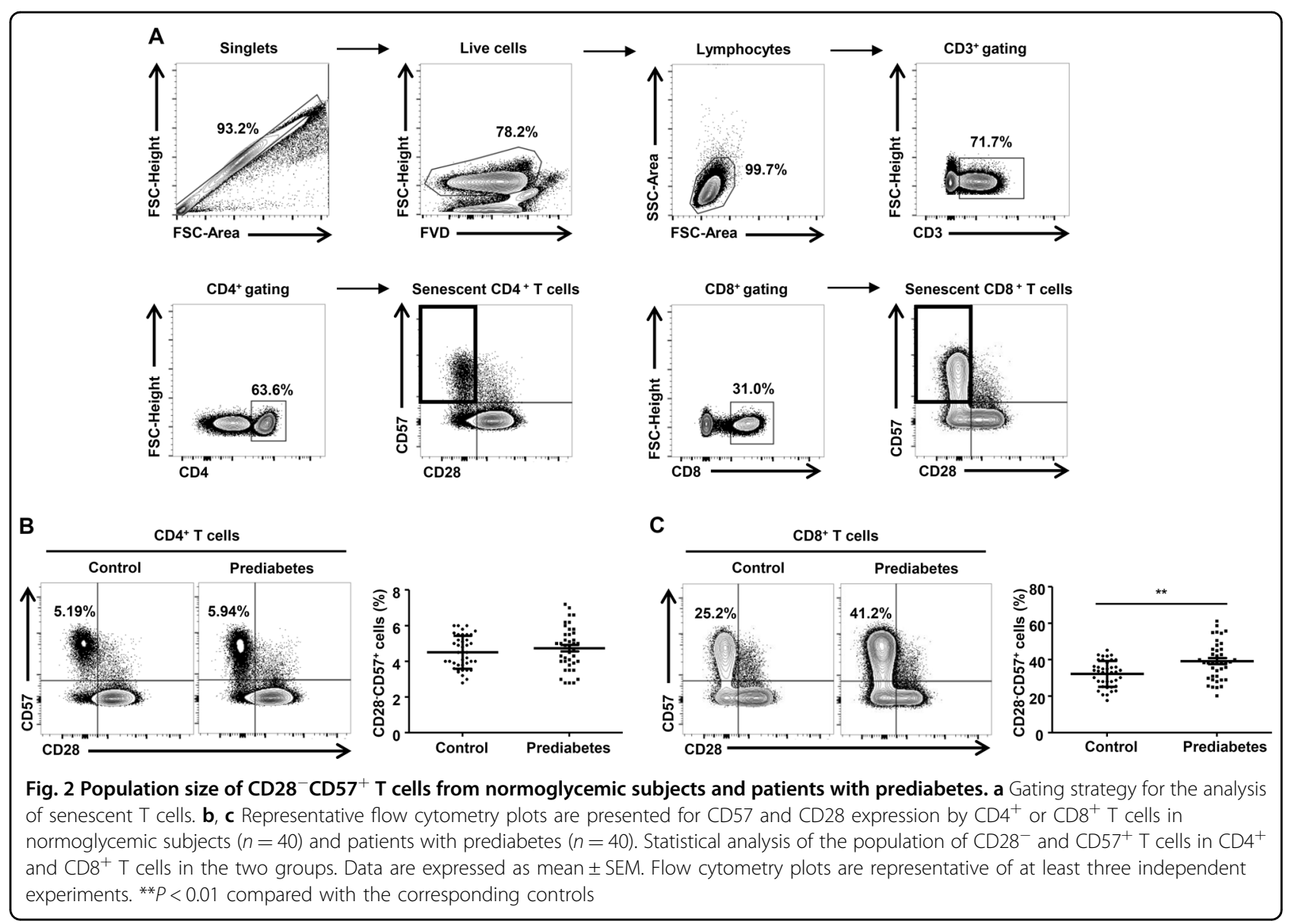

total $\mathrm{CD} 4+$ and $\mathrm{CD} 8+\mathrm{T}$ cells are significantly increased in the PBMCs from the patients with prediabetes compared with normal subjects. Interestingly, we also detected significant increases in the production of IFN- $\gamma$ and TNF- $\alpha$ in the senescent $C D 4^{+}$and $C D 8^{+} \mathrm{T}$ cells as well as in the CD57 ${ }^{-} \mathrm{T}$ cells (Fig. 3a-d). However, IL-17A production by senescent $\mathrm{T}$ cells was not detected in the PBMCs (Supplementary Fig. 5a, b). There was also no significant difference in IL-17A production between $\mathrm{CD}^{+}$and $\mathrm{CD}^{+} \mathrm{T}$ cells (Supplementary Fig. $5 \mathrm{a}, \mathrm{b}$ ). We also evaluated the expression of cytotoxic molecules in senescent $\mathrm{CD}^{+}$and $\mathrm{CD}^{+} \mathrm{T}$ cells from the study subjects. The population of granzyme B-producing senescent $\mathrm{CD}^{+}$cells was significantly larger in patients with prediabetes, but there was no significant difference in the expression of granzyme $\mathrm{B}$ in senescent $\mathrm{CD} 4^{+} \mathrm{T}$ cells between the two groups (Fig. 3e, f). The production of perforin was also greater in the senescent $\mathrm{CD}^{+}$and $\mathrm{CD}^{+}$cells from the patients with prediabetes (Fig. 3g, h). These data suggest that patients with prediabetes have a larger population of proinflammatory and cytotoxic senescent $\mathrm{CD} 8^{+} \mathrm{T}$ cells.
Patients with prediabetes have higher concentrations of ROS and glycolytic profile in their senescent $\mathrm{CDB}^{+} \mathrm{T}$ cells

ROS are implicated in hyperglycemia-induced inflammation $^{25}$. To investigate the relationship between hyperglycemia and ROS production in T cells, we measured ROS levels in the $\mathrm{CD} 4^{+} \mathrm{CD} 28^{-} \mathrm{T}$ cells as well as the $\mathrm{CD} 8^{+} \mathrm{CD} 28^{-} \mathrm{T}$ cells from normal subjects and patients with prediabetes. $\mathrm{CD} 4^{+} \mathrm{CD} 28^{-} \mathrm{T}$ cells contained similar concentrations of ROS, regardless of serum glucose status (Fig. 4a, b), whereas $\mathrm{CD}^{+} \mathrm{CD} 28^{-} \mathrm{T}$ cells from the patients with prediabetes had a higher capacity to produce ROS than those from normal subjects (Fig. 4c, d). Metabolic reprogramming orchestrates the functions of $\mathrm{T}$ cells ${ }^{26}$. Therefore, we measured the oxygen consumption rate (OCR) and extracellular acidification rate (ECAR) in $\mathrm{CD} 8^{+} \mathrm{CD} 28^{-} \mathrm{T}$ cells from normal subjects and the patients with prediabetes, and found no marked difference in the OCR of $\mathrm{CD} 8^{+} \mathrm{CD} 28^{-} \mathrm{T}$ cells between these groups (Fig. 4e). However, resting $\mathrm{CD} 8^{+} \mathrm{CD} 28^{-} \mathrm{T}$ cells showed a typical glycolytic profile, characterized by high elevated ECAR, consistent with abnormal glucose homeostasis (Fig. 4f). We also found that activated 


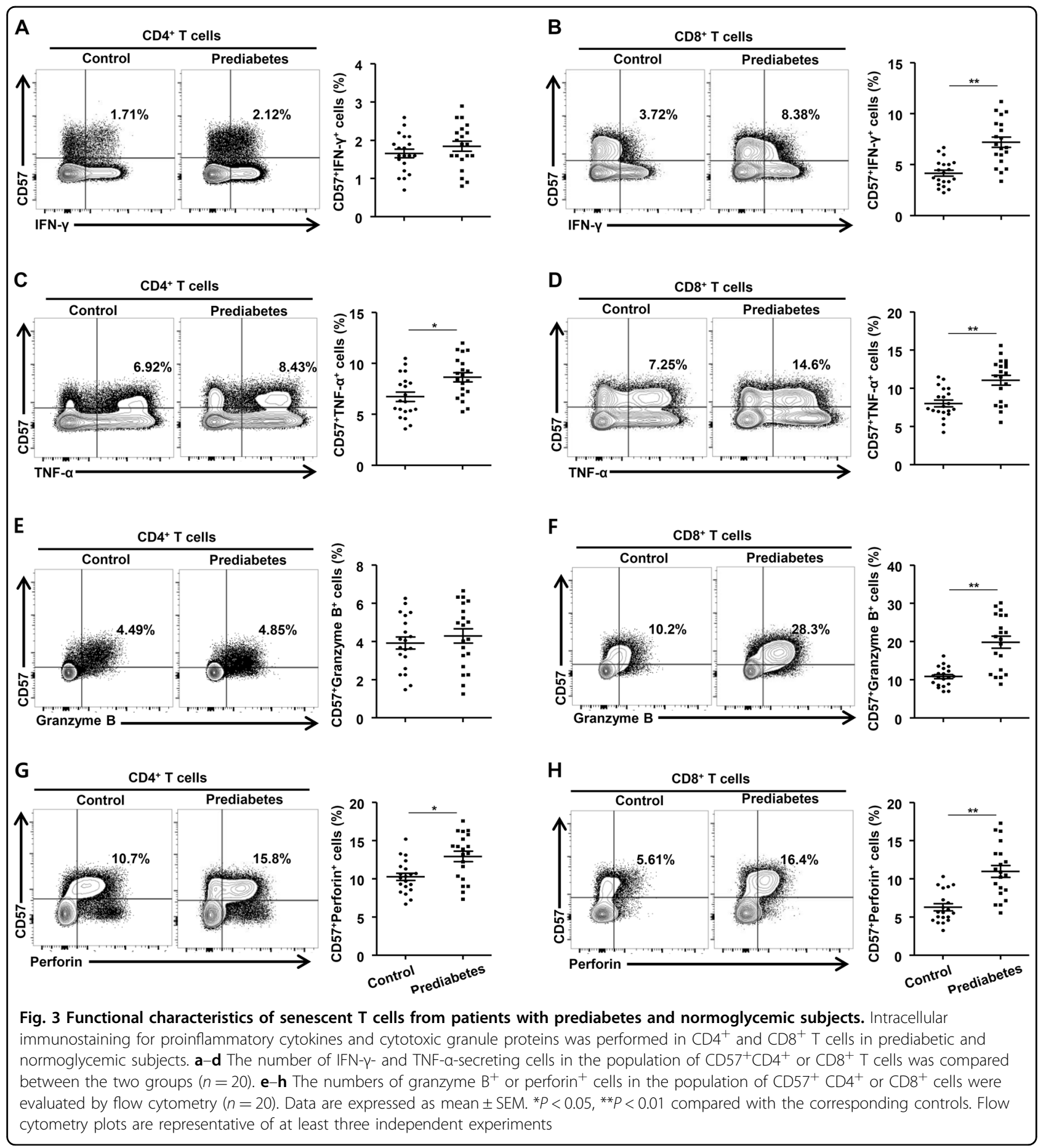

$\mathrm{CD} 8^{+} \mathrm{CD} 28^{-} \mathrm{T}$ cells using anti-CD3 antibodies showed a higher ECAR in the patients with prediabetes than in normal controls (Fig. 4g), suggesting that metabolically higher glycolytic potential of $\mathrm{CD}^{+} \mathrm{CD} 28^{-} \mathrm{T}$ cells is visible in the patients with abnormal glucose homeostasis. These findings indicate that the larger quantity of ROS produced by metabolically reprogrammed $\mathrm{CD} 8^{+} \mathrm{CD} 28^{-}$ $\mathrm{T}$ cells is associated with impaired glucose homeostasis.
T-cell senescence in prediabetes contributes to ATF5mediated GDF15 expression in the liver

Functional activation of senescent $\mathrm{CD} 8^{+} \mathrm{T}$ cells might be associated with the systemic inflammatory response in the body. Growth differentiation factor 15 (GDF15), a marker of oxidative stress and the inflammatory process, is a stress-responsive hepatokine that is increased in obesity, glucose intolerance, and cardiovascular diseases ${ }^{8}$. 


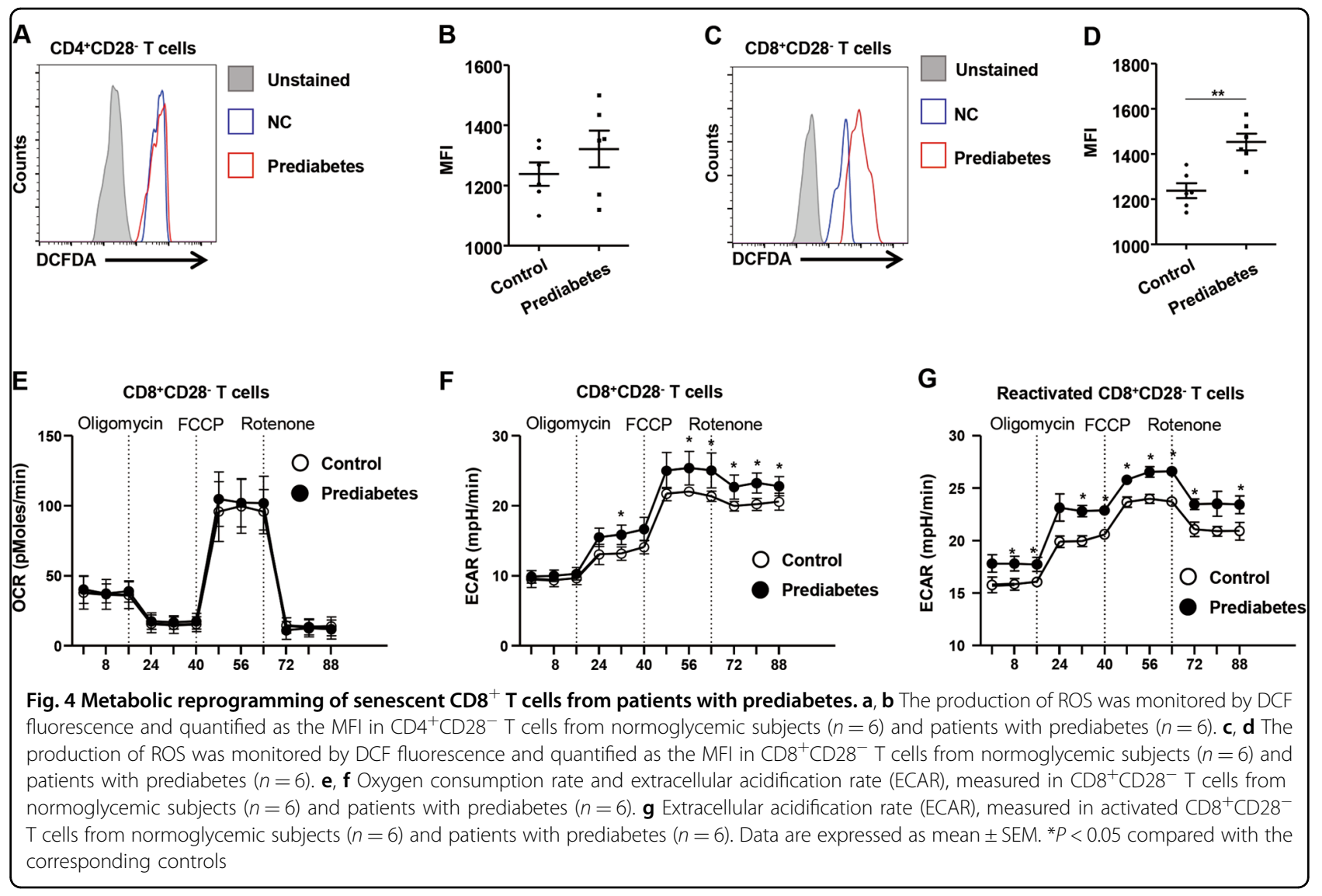

Activating transcription factor 5 (ATF5) is involved in liver-specific inflammatory response and translational regulation in response to environmental stresses ${ }^{22,27}$. We found that hepatic ATF5 expression was higher in patients with prediabetes than in controls (Fig. 5a, and Supplementary Table. 1). Next, to investigate the effect of senescent $\mathrm{CD} 8^{+} \mathrm{T}$ cells on hepatic ATF5 expression, we co-cultured $\mathrm{CD} 28^{+} \mathrm{CD} 57^{+}$or $\mathrm{CD} 28^{-} \mathrm{CD} 57^{+} \mathrm{T}$ cells with HepG2 cells using Transwell inserts. Interestingly, senescent $\mathrm{CD}^{+} \mathrm{T}$ cells induced ATF5 expression in HepG2 cells (Fig. 5b). Moreover, knockdown of ATF5 reduced the expression of GDF15 in HepG2 cells cocultured with senescent $\mathrm{CD}^{+} \mathrm{T}$ cells (Fig. 5c-e). In addition, we analyzed the correlation between serum GDF15 level and senescent $\mathrm{CD}_{4}^{+}$or $\mathrm{CD}^{+} \mathrm{T}$-cell numbers in the patients with prediabetes (Fig. 5f, g). Although we observed a weak correlation between the size of the population or the activation of senescent $\mathrm{CD} 4^{+} \mathrm{T}$ cells and the GDF15 level (Fig. 5f), the number of senescent $\mathrm{CD}^{+} \mathrm{T}$ cells was strongly correlated with serum GDF15 (Fig. 5g). Moreover, the production of IFN- $\gamma$ and TNF- $\alpha$ by the senescent $\mathrm{CD}^{+} \mathrm{T}$ cells exhibited a significant positive correlation with serum GDF15 (Fig. 5h-k). These data indicate that systemic inflammatory process are associated with the increased population and functional activation of senescent $\mathrm{CD}^{+} \mathrm{T}$ cells in patients with prediabetes.

\section{Effect of senescent $\mathrm{CD8}^{+} \mathrm{T}$ cells on hepatic gluconeogenesis}

To characterize the morphology of senescent $\mathrm{T}$ cells, subsets of human $\mathrm{CD}^{+}$and $\mathrm{CD} 8^{+} \mathrm{T}$ cells, including $\mathrm{CD} 28^{-} \mathrm{CD}_{57}{ }^{+}$and $\mathrm{CD} 28^{+} \mathrm{CD} 57^{-}$, were sorted (Fig.6a) and then stained with Giemsa. The nuclei of all the cells were usually round but could also be oval or slightly indented, with light blue cytoplasm (Fig. 6b). There was no difference in size or granularity among the four subsets (Fig. 6b). However, $\mathrm{CD} 8^{+} \mathrm{CD} 28^{-} \mathrm{CD} 57^{+} \mathrm{T}$ cells showed higher expression of proinflammatory cytokines than other subsets of $\mathrm{T}$ cells in resting condition (Fig. 6c).

Hepatic immune cells may influence regional hepatocytes, thereby modulating hepatic glucose metabolism. Therefore, we sought to demonstrate the existence of and to functionally analyze senescent $\mathrm{CD}^{+} \mathrm{T}$ cells in the liver. We isolated and analyzed hepatic immune cells from human subjects using fluorescence-activated cell sorting (FACS), thereby confirming the presence of senescent $\mathrm{CD}^{+} \mathrm{T}$ cells in the liver (Fig. 6d). Like peripheral 


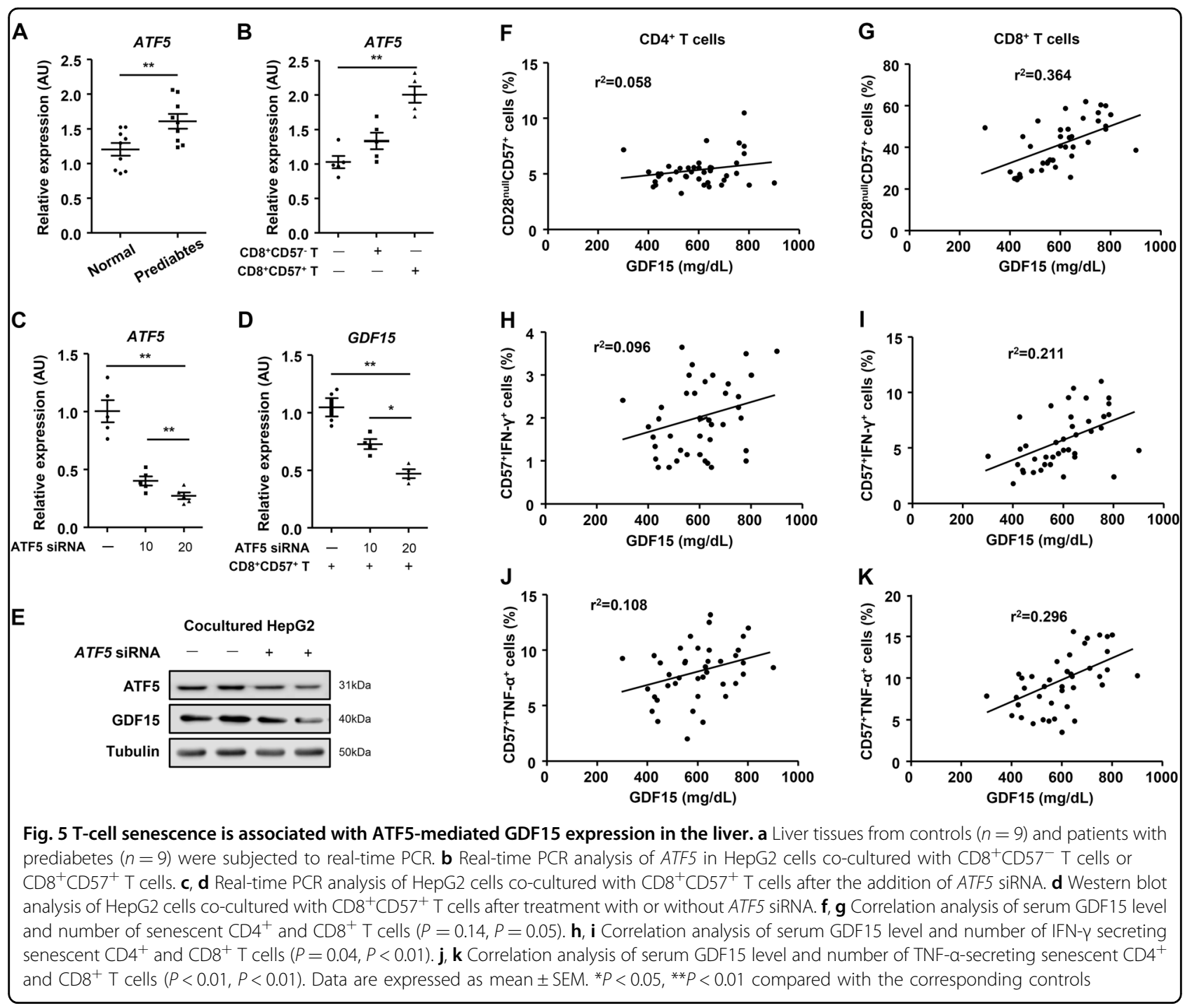

senescent $\mathrm{CD}^{+} \mathrm{T}$ cells, hepatic senescent $\mathrm{CD}^{+} \mathrm{T}$ cells also produced proinflammatory cytokine and cytotoxic molecules (Fig. 6d). The population of $\mathrm{CD} 28^{-} \mathrm{CD} 57^{+}$ senescent $\mathrm{CD}^{+} \mathrm{T}$ cells in liver was also significantly larger in patients with type 2 diabetes (Supplementary Fig. 6). Moreover, the number of senescent $\mathrm{CD} 8^{+} \mathrm{T}$ cells exhibited a positive correlation with fasting blood glucose (Fig. 6e). Next, to investigate the effect of hepatic senescent $\mathrm{CD}^{+} \mathrm{T}$ cells on hepatic gluconeogenesis, we cocultured senescent $\mathrm{CD} 8^{+} \mathrm{T}$ cells with HepG2 cells using Transwell inserts (Fig. 6f). Real-time PCR analysis showed that treatment with insulin significantly reduced the expression of G6PC and PCK1 in HepG2 cells (Fig. 6g). However, the suppression of gluconeogenic gene transcription by insulin was partially inhibited by co-culture with senescent $\mathrm{CD} 8^{+} \mathrm{T}$ cells (Fig. $6 \mathrm{~g}$ ). These data suggest that hepatic insulin sensitivity can be impaired by senescent $\mathrm{CD}^{+} \mathrm{T}$ cells.
Senescent $T$ cells are enriched in the liver of aged mice

Aging increases the prevalence of type 2 diabetes and systemic inflammation ${ }^{28}$, as well as the number of senescent $\mathrm{T}$ cells, in humans. Although the aging process is directly associated with the oligoclonal accumulation of $\mathrm{CD}^{+} \mathrm{CD}^{-} 8^{-} \mathrm{T}$ cells in humans ${ }^{29}$, the age-related loss of CD28 from $\mathrm{T}$ cells is not usually observed in mice ${ }^{30}$. However, it has been shown that the expression of CD153 (also known as a TNF superfamily protein) and programmed cell death 1 in $T$ cells increases with age in this species ${ }^{31,32}$. Therefore, we identified and characterized the senescent $\mathrm{T}$ cells in the liver of mice by FACS analysis using anti-CD153 and -CD279 antibodies. To determine the effect of aging on the size of the population of hepatic senescent $\mathrm{T}$ cells, we compared young (2-month-old) and old (16-month-old) mice. The old mice showed higher levels of fasting blood glucose and fasting insulin than the young mice (Supplementary Fig. 7a, b). We also found 


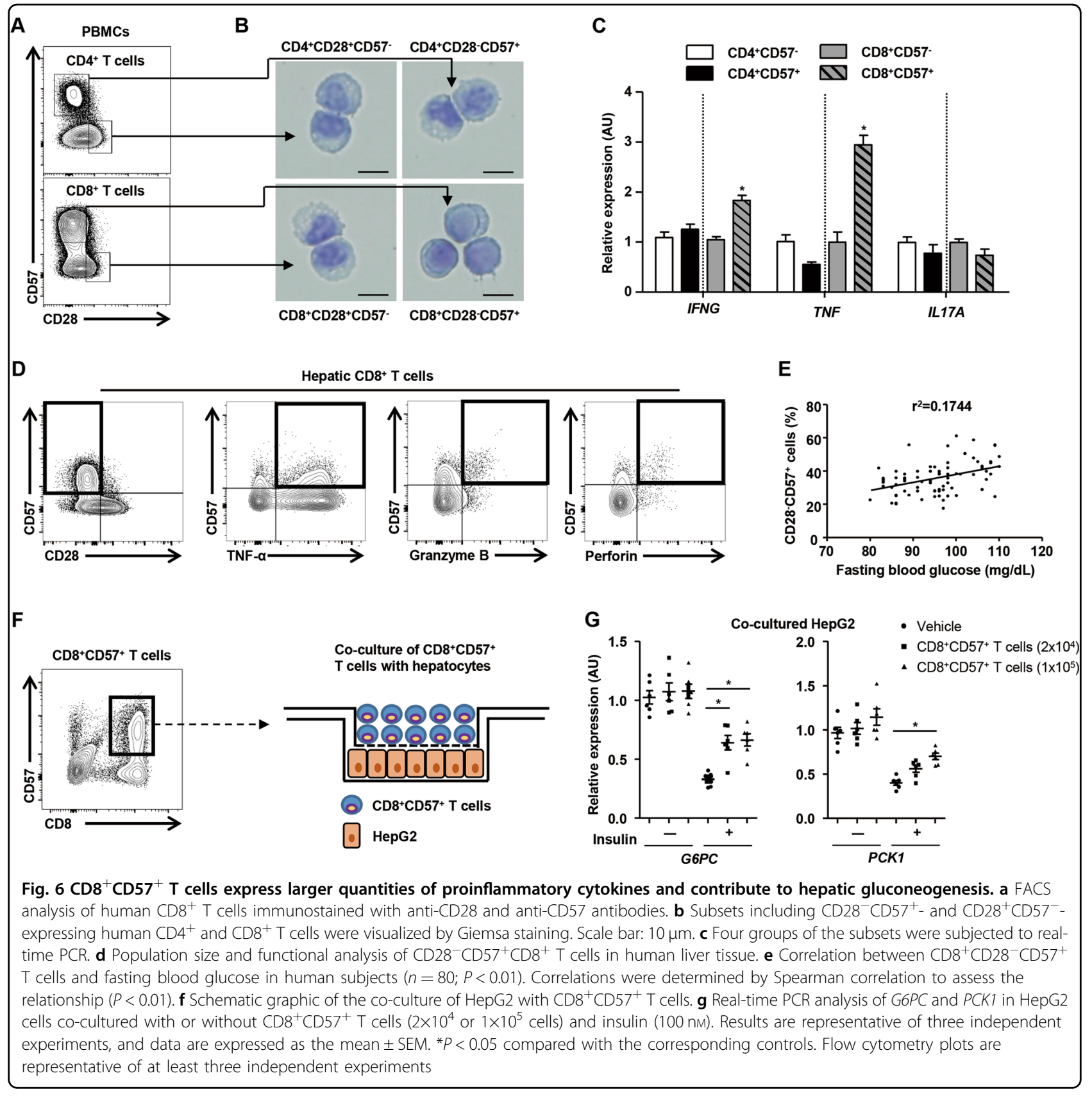

that primary hepatocytes isolated from 16-month-old mice showed an impairment in suppression of insulininduced gluconeogenic gene transcription (Supplementary Fig. 7c). Interestingly, livers of aged mice have much higher numbers of $\mathrm{CD} 4{ }^{+} \mathrm{CD} 44^{+} \mathrm{CD} 153^{+}$and $\mathrm{CD}^{+} \mathrm{CD} 44^{+} \mathrm{CD} 153^{+} \mathrm{T}$ cells (Supplementary Fig. $7 \mathrm{~d}, \mathrm{e}$ ). Moreover, the numbers of $\mathrm{CD} 4{ }^{+} \mathrm{CD} 44^{+} \mathrm{CD} 279^{+}$and $\mathrm{CD}^{+} \mathrm{CD} 44^{+} \mathrm{CD} 279^{+} \mathrm{T}$ cells in the liver were greater in old mice than young mice (Supplementary Figure $7 \mathrm{f}, \mathrm{g}$ ). The numbers of $\mathrm{CD} 4^{+} \mathrm{CD} 44^{+} \mathrm{CD} 153^{+} \mathrm{CD} 279^{+}$and
$\mathrm{CD}^{+} \mathrm{CD} 44^{+} \mathrm{CD} 153^{+} \mathrm{CD} 279^{+} \mathrm{T}$ cells were also higher in the liver of old mice (Supplementary Fig. 7h, i). To evaluate the functional characteristics of the hepatic senescent $\mathrm{T}$ cells, we assessed TNF- $\alpha$ production by $\mathrm{CD} 4{ }^{+} \mathrm{CD} 44^{+} \mathrm{CD} 153^{+}$and $\mathrm{CD} 44^{+} \mathrm{CD} 44^{+} \mathrm{CD} 279^{+} \mathrm{T}$ cells in the liver of young and old mice. TNF- $\alpha$ expression in the $\mathrm{CD} 4{ }^{+} \mathrm{CD} 44^{+} \mathrm{CD} 153^{+}$and $\mathrm{CD} 44^{+} \mathrm{CD} 44^{+} \mathrm{CD} 279^{+} \mathrm{T}$ cells was significantly higher in the liver of old than young mice (Supplementary Fig. 7j-m). In old mice, the expression of TNF- $\alpha$ was also high in $\mathrm{CD}^{+} \mathrm{CD} 44^{+} \mathrm{CD} 153^{+}$and 
$\mathrm{CD}^{+} \mathrm{CD} 44^{+} \mathrm{CD} 279^{+} \mathrm{T}$ cells from the liver (Supplementary Fig. 7j-m). These results indicate that $\mathrm{CD} 153^{+} \mathrm{CD} 279^{+} \mathrm{T}$ cells with features of inflammation are present in larger numbers in the livers of aged mice with glucose intolerance.

\section{Feeding a HFD induces T-cell senescence in mouse liver}

Diet-induced obesity is associated with an altered hepatic immune microenvironment, which leads to metabolic deterioration in the liver ${ }^{33}$. Thus, to explore the effect of a high fat diet (HFD) on T-cell senescence in the liver, male C57BL/6J mice were fed either a normal chow diet (NCD) or a HFD for 8 weeks. We identified and further characterized senescent $\mathrm{T}$ cells in the liver of mice fed a HFD or a NCD. The mice fed a HFD showed a remarkable increase in the surface expression of CD44 and lower expression of $\mathrm{CD} 62 \mathrm{~L}$ in $\mathrm{CD}_{4}^{+}$and $\mathrm{CD} 8^{+}$ $\mathrm{T}$ cells in their livers (Supplementary Fig. 8a, b). In addition, the populations of $\mathrm{CD}_{4} 4^{+} \mathrm{IFN}-\gamma^{+}$and $\mathrm{CD} 44^{+} \mathrm{TNF}-\alpha^{+}$subsets were increased in $\mathrm{CD}^{+}$and $\mathrm{CD}^{+} \mathrm{T}$ cells from the livers of mice fed a HFD (Fig. $7 \mathrm{a}-\mathrm{c}$ ). The mice fed a HFD exhibited an increase in the population of infiltrating monocytes $\left(\mathrm{CD} 11 \mathrm{~b}^{+}\right.$Ly6$\mathrm{C}^{\text {high }} \mathrm{LyG}^{\text {low }}$ ) in the livers (Supplementary Fig. 8c). We also found that the populations of $\mathrm{CD} 44^{+} \mathrm{CD} 153^{+}$in $\mathrm{CD}^{+}$and $\mathrm{CD}^{+} \mathrm{T}$ cells were significantly larger in the livers of mice fed a HFD (Fig. 7d, e and Supplementary Fig. 9a). Moreover, the surface expression of CD279 in $\mathrm{CD} 4{ }^{+} \mathrm{CD} 44^{+}$and $\mathrm{CD} 8^{+} \mathrm{CD} 44 \mathrm{~T}$ cells was markedly higher in the livers of mice fed a HFD (Fig. $7 \mathrm{~d}$, e and Supplementary Fig. 9a). The expression of TNF- $\alpha$ and IFN- $\gamma$ was also higher in $\mathrm{CD} 44^{+} \mathrm{CD} 153^{+}$and $\mathrm{CD} 44^{+} \mathrm{CD} 279^{+}$of $\mathrm{CD} 4^{+}$as well as $\mathrm{CD} 8^{+} \mathrm{T}$ cells from the livers of mice fed a HFD than in those from the livers of mice fed a NCD (Fig. 7f, g). Next, we investigated the migration of senescent $\mathrm{CD} 8^{+} \mathrm{T}$ cells in metabolic organs including liver and adipose tissue. Senescent $\mathrm{CD} 8^{+} \mathrm{T}$ cells were isolated from male CD45.1 $1^{+}$mice and transferred to $\mathrm{CD} 45.2^{+}$mice. We found that $\sim 1 \%$ of adoptively transplanted senescent $\mathrm{CD}^{+} \mathrm{T}$ cells accumulated in the liver (Supplementary Fig. 9b, c), but we could not detect transplanted cells in the epididymal adipose tissues of the recipient mice (Supplementary Fig. 9b, c). To further confirm the immunometabolic role of senescent $\mathrm{CD} 8^{+}$ $\mathrm{T}$ cells in the liver, we adoptively transferred $\mathrm{CD}^{+} \mathrm{CD} 44^{+} \mathrm{CD} 153^{+} \mathrm{T}$ cells isolated from the spleens of mice fed a HFD or a NCD into young (2-month-old) mice via tail vein. Adoptive transfer of $\mathrm{CD} 8^{+} \mathrm{CD} 44^{+} \mathrm{CD} 153^{+}$ $\mathrm{T}$ cells reduced glucose disposal rates in young mice (Supplementary Fig. 9d). Moreover, the recipients of $\mathrm{CD}^{+} \mathrm{CD} 44^{+} \mathrm{CD}_{153^{+}} \mathrm{T}$ cells from mice fed a HFD exhibited significant aggravation of glucose tolerance compared to control mice transferred from mice fed a $\mathrm{NCD}$ (Fig. 7h). Adoptive transfer of $\mathrm{CD} 8^{+} \mathrm{CD} 44^{+} \mathrm{CD} 153^{+}$
$\mathrm{T}$ cells also led to a significant deterioration in insulin sensitivity in mice (Supplementary Fig. 9e). $\mathrm{CD}^{+} \mathrm{CD} 44^{+} \mathrm{CD}_{153}{ }^{+} \mathrm{T}$ cells from the mice fed a HFD exacerbated insulin resistance than those from the mice fed a NCD (Fig. 7i). Reducing ROS with $\mathrm{N}$-acetylcysteine improves abnormal glucose homeostasis caused by injection of $\mathrm{CD}^{+} \mathrm{CD} 44^{+} \mathrm{CD} 153^{+} \mathrm{T}$ cells from the mice fed a HFD (Fig. 7h, i). Hepatic expression of Atf5 and Gdf15 in mice injected with $\mathrm{CD} 8^{+} \mathrm{CD} 44^{+} \mathrm{CD} 153^{+} \mathrm{T}$ cells from the mice fed a HFD was remarkably reduced by treatment with $N$-acetylcysteine (Fig. 7j). Furthermore, we co-cultured the murine hepatocytes with hepatic senescent $\mathrm{CD}^{+} \mathrm{T}$ cells using Transwell inserts in in vitro (Supplementary Fig. 10a). Treatment with $N$-acetylcysteine reduced the transcription of Atf5 and Gdf15 in primary hepatocytes co-cultured with hepatic senescent $\mathrm{CD}^{+} \mathrm{T}$ cells (Supplementary Fig. 10b). We also treated primary hepatocytes with conditioned media of hepatic senescent $\mathrm{CD} 8^{+} \mathrm{T}$ cells treated with $\mathrm{N}$-acetylcysteine or vehicle. Conditioned media from hepatic senescent $\mathrm{CD} 8^{+}$ T cells treated with $N$-acetylcysteine decreased the transcription of Atf5 and Gdf15 in hepatocytes (Supplementary Fig. 10c). This finding supports that ROS production by senescent $\mathrm{CD} 8^{+} \mathrm{T}$ cells contributes to mitochondrial stress response in the hepatocytes. These findings implicate distinct effects of murine T-cell senescence on obesity and abnormal glucose homeostasis.

\section{Discussion}

Chronic inflammation is closely associated with a higher risk of cardiovascular disease, and seems to contribute to insulin resistance in patients with prediabetes ${ }^{21}$. Moreover, in a large representative population sample, immune and inflammatory responses were strongly stimulated in subjects with prediabetes ${ }^{34}$. We also showed in the present study that molecules involved in T-cell activation were upregulated in PBMCs from patients with prediabetes. In previous studies, $\mathrm{T}$ cells have been implicated in the pathogenesis of insulin resistance in rodents and humans ${ }^{24,35-38}$, and have been shown to contribute to the progression of tissue inflammation through the release of proinflammatory cytokines, such as IFN- $\gamma$ and TNF- $\alpha^{39}$.

Although $\mathrm{T}$ cells proliferate by clonal expansion and differentiate into memory or effector $\mathrm{T}$ cells throughout the lifetime of an organism, impairment in memory formation by antigen-specific $\mathrm{T}$ cells leads to senescence or exhaustion of $\mathrm{T}$ cells, according to the size of the antigenic load or the degree of stimulation ${ }^{40}$. Although the role of senescent $\mathrm{CD} 28^{-} \mathrm{T}$ cells, a population of terminally differentiated memory $\mathrm{T}$ cells, is not fully understood, they have been shown to be more numerous in the presence of cardiovascular diseases and immune disorders $^{10,41}$. In addition, treatment with a statin significantly reduces the number of peripheral $\mathrm{CD} 4{ }^{+} \mathrm{CD} 28^{-}$ 


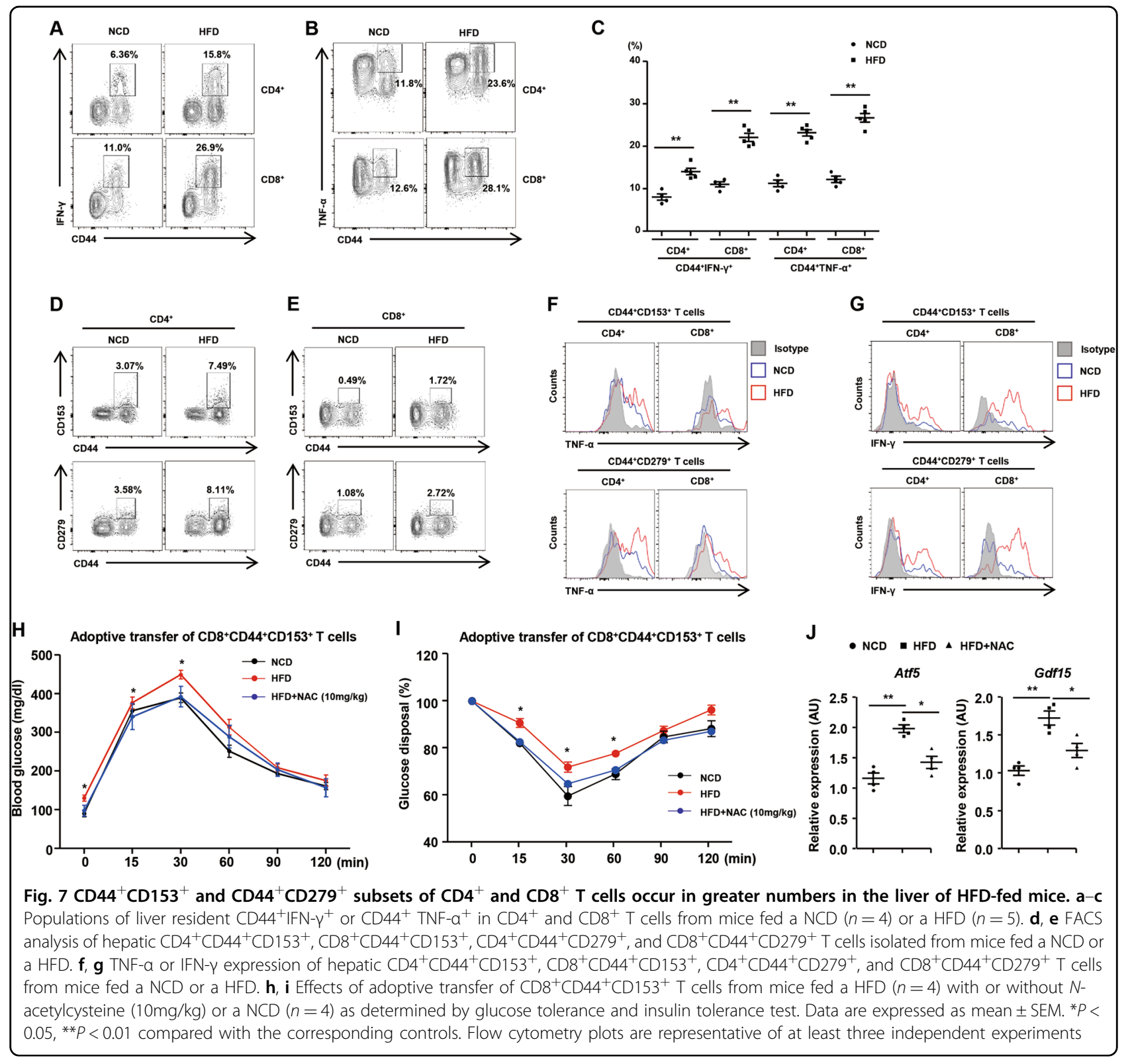

$\mathrm{T}$ cells and IFN- $\gamma$ production by $\mathrm{CD} 4{ }^{+} \mathrm{CD} 28^{-} \mathrm{T}$ cells in patients with acute coronary syndrome ${ }^{42,43}$. In the present study, the population of peripheral $\mathrm{CD} 28^{-} \mathrm{CD} 57^{+} \mathrm{CD} 8^{+}$ $\mathrm{T}$ cells was also larger in patients with prediabetes than in normal controls. The expression of proinflammatory cytokines and cytotoxic enzymes was also significantly higher in $\mathrm{CD} 28^{-} \mathrm{CD} 57^{+} \mathrm{CD} 8^{+} \mathrm{T}$ cells from patients with prediabetes. Although there is no difference in the population of senescent $\mathrm{CD} 4^{+} \mathrm{T}$ cells between patients with prediabetes and control subjects, the population of senescent $C D 4^{+} \mathrm{T}$ cells producing TNF- $\alpha$ and Perforin is significantly increased in patients with prediabetes compared with control subjects. This discrepancy between population and function of senescent $\mathrm{CD} 4^{+} \mathrm{T}$ cells might originate from disease severity. It is also possible that changes in the population of senescent $\mathrm{CD} 4^{+} \mathrm{T}$ cells may follow the functional changes of senescent $\mathrm{CD} 4^{+} \mathrm{T}$ cells in the development of type 2 diabetes in humans. Patients with overt type 2 diabetes might show higher population of senescent $\mathrm{CD}^{+}$and $\mathrm{CD} 8^{+} \mathrm{T}$ cells in PBMCs compared with normal controls. However, further studies are needed to validate whether hyperglycemia progression increases the population of senescent $\mathrm{CD}^{+}{ }^{+} \mathrm{T}$ cells in PBMCs.

During an immune response, the metabolic shift from oxidative phosphorylation to glycolysis supports the 
activation and proliferation of $\mathrm{CD} 4^{+}$and $\mathrm{CD} 8^{+} \mathrm{T}$ cells. A recent study also revealed that human $\mathrm{CD} 8^{+} \mathrm{CD} 28^{-}$ $\mathrm{T}$ cells have an increased capacity to use glycolysis, associated with the loss of SIRT $1^{44}$. Moreover, intracellular ROS are necessary for driving and maintaining $\mathrm{T}$-cell activation-induced metabolic reprogramming ${ }^{45}$. Oxidative stress is also induced in hyperglycemia, and the overproduction of ROS contributes to the pathogenesis of diabetic complications ${ }^{46}$. Therefore, metabolic switching by a senescent population of terminally differentiated $\mathrm{T}$ cells can be implicated in the production of ROS and proinflammatory cytokines, which leads to a systemic inflammatory response and metabolic deterioration. Consistent with previous reports, we found that $\mathrm{CD} 8^{+} \mathrm{CD} 28^{-} \mathrm{T}$ cells had a higher capacity to produce ROS and exhibited glycolytic profile in patients with abnormal glucose homeostasis compared with normal subjects. In addition, we demonstrated that these $\mathrm{CD} 8^{+} \mathrm{CD} 28^{-} \mathrm{T}$ cells reside within the liver and are more numerous in the liver of aged and HFD-fed mice. These suggest that $\mathrm{T}$-cell senescence-mediated reprogramming of metabolic pathways may be associated with development of diabetes and its complications, as well as other aging-related diseases.

- In conclusion, we identified a link between the numbers and secretion of effector molecules by senescent $\mathrm{T}$ cells, and blood glucose status, in humans and mice. We also present evidence that senescent $\mathrm{CD}^{+} \mathrm{T}$ cells may contribute to inflammatory response during the development of diabetes. Finally, we demonstrated that the presence of hepatic senescent $\mathrm{T}$ cells is associated with abnormal glucose homeostasis in aged and dietinduced obese mice. Therefore, this study defines a new clinically relevant concept of a T-cell senescence-mediated inflammatory response in the pathophysiology of diabetes.

\section{Materials and methods \\ Study population}

We recruited 80 participants who did not have diabetes mellitus in Chungnam National University Hospital between October 2015 and April 2017. Patients with any of the following conditions were excluded from the study: previous coronary heart disease, history of any arrhythmia, malignant hypertension, severe pulmonary disease, acute or chronic kidney disease (estimated glomerular filtration rate $<30 \mathrm{~mL} / \mathrm{min} / 1.73 \mathrm{~m}^{2}$ ), anemia (hemoglobin $<12 \mathrm{~g} / \mathrm{dL}$ ), history of any malignant or inflammatory disease, current liver disease, or high plasma aspartate transaminase or alanine transaminase $(>80 \mathrm{IU} / \mathrm{L})$. The participants were divided into two groups: normoglycemic $(n=40)$ and prediabetic $(n=40)$. Age- and gender-matched, healthy control subjects and patients with prediabetes were randomly selected and evaluated by history taking, physical examination, laboratory testing, and flow cytometry analysis. Prediabetes was defined by the presence of the following: (i) IFG (blood glucose: 100-125 mg/dL); (ii) IGT (blood glucose: $140-199 \mathrm{~mL} / \mathrm{dL}$ after a $2 \mathrm{~h}$ oral glucose tolerance test); and (iii) glycated hemoglobin of $5.7-6.5 \%$. Liver biopsies from the patients did not contain tumor cells and showed no signs of viral hepatitis.

This study was reviewed and approved by the Institutional Review Board of Chungnam National University Hospital (CNUH 2015-09-042), according to the standards of the Declaration of Helsinki. Written and oral informed consent, documented by the Department of Internal Medicine of Chungnam National University Hospital in South Korea, was obtained from all of the participants prior to their inclusion in the study.

\section{Mice}

Male C57BL/6 wild-type mice were purchased from the Jackson Laboratory (Bar Harbor, ME, USA). All mice were maintained in a controlled environment $(12 \mathrm{~h}$ light/12 h dark cycle; humidity: 50-60\%; ambient temperature: $22 \pm 2{ }^{\circ} \mathrm{C}$ ) in a specific pathogen-free animal facility at the Chungnam National University Hospital Preclinical Research Center. Mice were fed either a NCD or a HFD (Research Diets. Inc., New Brunswick, NJ, USA), starting when the mice were 6-week-old, and continuing for 8 weeks. Young (2-month-old) and old (16-month-old) mice were also used to investigate the effect of aging on the senescence of murine $\mathrm{T}$ cells in the liver. All animals received humane care according to the criteria outlined in the Guide for the Care and Use of Laboratory Animals, published by the National Institutes of Health, and all experimental procedures were approved by the Institutional Animal Care and Use Committee of the Chungnam National University School of Medicine.

\section{Preparation of PBMCs}

Peripheral blood samples $(8-10 \mathrm{~mL}$ each) were obtained from all participants, transferred aseptically into $50 \mathrm{~mL}$ polystyrene centrifuge tubes containing ethylenediaminetetraacetic acid (Sigma-Aldrich, Dorset, UK) as an anticoagulant, and gently mixed. PBMCs were isolated by centrifugation on a Ficoll-Paque density gradient (GE Healthcare Life Science, Buckinghamshire, UK) at room temperature. After centrifugation, the PBMC layer was collected and washed in Dulbecco's phosphate-buffered saline . The isolated PBMCs were resuspended in $2 \mathrm{~mL}$ Rosewell Park Memorial Institute (RPMI)-1640 medium (Welgene, Daegu, South Korea), and trypan blue dye exclusion testing was used to determine the number of viable cells in the suspension. 


\section{FACS analysis of human PBMCs}

PBMCs were incubated with directly fluorochromeconjugated monoclonal antibodies for $40 \mathrm{~min}$ at $4{ }^{\circ} \mathrm{C}$. The antibodies used in this study were anti-CD3-PerCP-Cy5.5, anti-CD3-PE-Cy7, anti-CD4-AF700, anti-CD8-PE, antiCD8-APC, anti-CD28-APC, anti-CD57-FITC, fixable viability dye-APC-Cy7, anti-IFN)- $\gamma$-PE-Cy7, anti-TNF- $\alpha-A P C$, anti-IL-17A-APC, anti-perforin-PerCP-Cy5.5, antigranzyme B-PE, and anti-FVD-APC-Cy7 (all supplied by eBioscience, San Diego, CA, USA). PBMCs were stimulated with phorbol-myristate acetate/ionomycin/brefeldin A/ monensin for $5 \mathrm{~h}$. The cells were fixed and permeabilized using a Fixation/Permeabilization Buffer kit (eBioscience, San Diego, CA, USA). The permeabilized cells were washed and resuspended in $1 \%$ formaldehyde and further stained for intracellular cytokines and cytotoxic molecules with anti-IFN- $\gamma$-PE-Cy7, anti-TNF- $\alpha$-APC, anti-IL-17A-APC, anti-perforin-PerCP-Cy5.5, and anti-granzyme B-PE. Multicolor flow cytometry was performed using a BD FACSCanto II Flow Cytometer (BD Biosciences, San Jose, CA, USA), and the data were analyzed using Flowjo software (Tree Star, Ashland, OR, USA).

\section{Microarray analysis using bioinformatic tools}

Total RNA was prepared from PBMCs obtained from patients who had been newly diagnosed with diabetes, and age- and sex-matched control subjects. RNA amplification and labeling were performed with a Low RNA Input Linear Amplification kit PLUS (Agilent Technologies, Santa Clara, CA, USA). Array hybridization and scanning were performed with a DNA microarray chip and scanner (Agilent Technologies). Data were analyzed using Feature Extraction and GeneSpring Software (Agilent Technologies). The Database for Annotation, Visualization, and Integrated Discovery (DAVID) of the NIH was approved to detect functional gene annotation clusters, based on gene expression profiling by gene annotation enrichment analysis. Moreover, differentially expressed genes were then subjected to hierarchical clustering and phenotype ontology using Network2Canvas (http://maayanlab.net/ $\mathrm{N} 2 \mathrm{C} /$ ). Phenotype categories were visualized on the grid according to gene-list similarity, with enriched categories being indicated by circles. In addition, Gene Set Enrichment Analysis (http://www.broadinstitute.org/ gsea) was performed on transcriptome data for PBMCs from normal subjects and patients with prediabetes. Microarray analysis was carried out with $\mathrm{R}$ package v3.2.5, available at http://www.r-project.org. A heatmap was produced by color-coding standardized log gene expression levels (mean, zero; standard deviation, one). Probesets are shown hierarchically clustered by similarity, based on Euclidean distance and the Ward aggregation algorithm.

\section{Measurement of ROS in PBMCs}

The PBMCs $\left(2 \times 10^{5}\right.$ cells $)$ were washed with PBS and incubated with surface immune-fluorescence-conjugated antibodies for $30 \mathrm{~min}$. The cells were incubated with the ROS detection reagent 6-chloromethyl-2',7'-dichlorodihydrofluorescein diacetate, acetyl ester (CM-H2DCFDA from Invitrogen, Carlsbad, CA, USA) at $37^{\circ} \mathrm{C}$ for 15 min, while other cells incubated with PBS were used as negative controls. Oxidation of the CM-H2DCF-DA probe was analyzed by excitation at $492-495 \mathrm{~nm}$ and the monitoring of the fluorescent emission at $517-527 \mathrm{~nm}$ using a BD FACSCanto II Flow Cytometer (BD Biosciences, San Jose, CA, USA). A histogram of the relative fluorescence intensities was used to compare intracellular ROS generation in PBMC subsets.

\section{Measurement of OCR and ECAR}

Mitochondrial OCR and ECAR were determined using a Seahorse XF-96 Extracellular Flux Analyzer (Seahorse Bioscience Inc., North Billerica, MA, USA) in 96-well plates. $\mathrm{CD} 8^{+} \mathrm{CD} 28^{-} \mathrm{T}$ cells were sorted by FACS Aria II (BD Bioscience, San Jose, CA, USA) using surface immune-fluorescence-conjugated antibodies. Resting $\mathrm{CD}^{+} \mathrm{CD} 28^{-} \mathrm{T}$ cells were seeded onto Seahorse XF-96 plates at a density of 50,000 cells per well. The cells were washed and incubated with RPMI-1640 medium lacking sodium bicarbonate at $37^{\circ} \mathrm{C}$ in a non- $\mathrm{CO}_{2}$-containing incubator for $1 \mathrm{~h}$. The medium and mitochondrial OXPHOS inhibitors were adjusted to $\mathrm{pH} 7.4$ on the day of the OCR assay. Measurements of OCR and ECAR were obtained under basal conditions and after adding $1 \mu \mathrm{M}$ oligomycin, $0.5 \mu \mathrm{M}$ FCCP, and $0.5 \mu \mathrm{m}$ rotenone. OCR and ECAR were automatically calculated and recorded by the sensor cartridge and Seahorse XF-96 software.

\section{Hepatocyte isolation}

As described previously ${ }^{47,48}$, murine hepatocytes were isolated from mice by in situ collagenase perfusion, followed by differential centrifugation on a Percoll (GE Healthcare, Buckingham, UK) density gradient, after filtering the cell suspension using a $70 \mu \mathrm{m}$ nylon mesh (BD Falcon, NJ, USA). Isolated hepatocytes were cultured in low glucose $(1.0 \mathrm{~g} / \mathrm{L})$ Dulbecco's modified Eagle's medium supplemented with 10\% fetal bovine serum (Invitrogen, Carlsbad, CA, USA) and 1\% penicillin/streptomycin (Invitrogen, Carlsbad, CA, USA) at a density of $1 \times 10^{5}$ cells/well on 12-well plates.

\section{Adoptive transfer of $\mathrm{CD8} 8^{+} \mathrm{CD} 44^{+} \mathrm{CD} 153^{+} \mathrm{T}^{\top}$ cells into recipient mice}

$\mathrm{CD} 8{ }^{+} \mathrm{CD} 44^{+} \mathrm{CD} 153^{+} \mathrm{T}$ cells were isolated from the spleen of mice fed a HFD or a NCD for 8 weeks. A total of $1 \times 10^{6}$ cells diluted with RPMI medium were injected to young (2-month-old) mice through tail vein, two times per week for 2 weeks. The vehicle was also similarly injected into the 
control young (2-month-old) mice. $\mathrm{N}$-acetylcysteine (SigmaAldrich, St. Louis, MO, USA) was administered intraperitoneally at a dose of $10 \mathrm{mg} / \mathrm{kg}$ dissolved in $0.5 \mathrm{~mL}$ of phosphate-buffered saline three times per week for 2 weeks.

\section{Statistical analysis}

All continuous variables are reported as the mean \pm standard deviation. Statistical significance was defined as $P<0.05$ and obtained using two-tailed Student's $t$ test or two-way analysis of variance, as appropriate. Categorical variables were calculated as a percentage of the group total. To analyze the strength of the relationship between continuous variables, Pearson correlation coefficients were used. Calculation of the statistical significance was based on the assumption that values exhibit a Gaussian distribution. Statistical analysis was performed using Graph Pad PRISM 6 or R package v3.2.5.

\section{Acknowledgements}

This work was supported by the Basic Science Research Program, through the National Research Foundation of Korea (NRF), funded by the Ministry of Science, ICT, and Future Planning, Korea (NRF-2015R1C1A1A01052432; NRF2018R1C1B6004439), the Research fund of the Korean Diabetes Association ( $\mathrm{H}$ S. Yi, 2017F-1), and NRF-2016R1D1A1A09916900; NRF-2017R1E1A1A01075126.

\begin{abstract}
Author details
${ }^{1}$ Research Center for Endocrine and Metabolic Diseases, Chungnam National University Hospital, Chungnam National University School of Medicine, Daejeon 35015, Republic of Korea. ${ }^{2}$ Department of Internal Medicine, Chungnam National University School of Medicine, Daejeon 35015, Republic of Korea. ${ }^{3}$ Laboratory of Liver Research, Biomedical Science and Engineering Interdisciplinary Program, Korean Advanced Institute of Science and Technology, Daejeon 34141, Republic of Korea. ${ }^{4}$ Division of Digestive and Liver Diseases, Department of Medicine, Cedars-Sinai Medical Center, Los Angeles, CA 90048, USA. ${ }^{5}$ Department of Medical Science, Chungnam National University School of Medicine, 266 Munhwaro, Daejeon 35015, Republic of Korea. ${ }^{6}$ Department of Internal Medicine, Korea University College of Medicine, Seoul 08308, Republic of Korea. 'Division of Rheumatology, Department of Internal Medicine, Gyeongsang National University School of Medicine, 79, Gangnam-ro, Jinju, Gyeongnam 660-702, Republic of Korea. ${ }^{8}$ Department of Surgery, Chungnam National University School of Medicine, Daejeon 35015, Republic of Korea
\end{abstract}

\section{Author contributions}

HY and BJK conceived and designed the study. HY, SYK, JTK, JSM, and MK performed most of the experiments and analyzed the data. YEK, KHJ, JHL, HJK, $K C, Y L, M S$, and BJK analyzed the data and contributed to discussion. HY and BJK wrote the manuscript. All authors reviewed the manuscript.

\section{Conflict of interest}

The authors declare that they have no conflict of interest.

\section{Publisher's note}

Springer Nature remains neutral with regard to jurisdictional claims in published maps and institutional affiliations.

Supplementary Information accompanies this paper at (https://doi.org/ 10.1038/s41419-019-1494-4).

Received: 24 October 2018 Revised: 26 February 2019 Accepted: 28 February 2019

Published online: 13 March 2019

\section{References}

1. Baker, R. G., Hayden, M. S. \& Ghosh, S. NF-kappaB, inflammation, and metabolic disease. Cell Metab. 13, 11-22 (2011).

2. Wellen, K. E. \& Hotamisligil, G. S. Inflammation, stress, and diabetes. J. Clin. Invest 115, 1111-1119 (2005).

3. Stamler, J., Vaccaro, O., Neaton, J. D. \& Wentworth, D. Diabetes, other risk factors, and 12-yr cardiovascular mortality for men screened in the Multiple Risk Factor Intervention Trial. Diabetes Care. 16, 434-444 (1993).

4. Moller, D. E. Potential role of TNF-alpha in the pathogenesis of insulin resistance and type 2 diabetes. Trends Endocrinol. Metab. 11, 212-217 (2000).

5. Spranger, J. et al. Inflammatory cytokines and the risk to develop type 2 diabetes: results of the prospective population-based European Prospective Investigation into Cancer and Nutrition (EPIC)-Potsdam Study. Diabetes 52, 812-817 (2003).

6. Bardini, G., Dicembrini, I., Cresci, B. \& Rotella, C. M. Inflammation markers and metabolic characteristics of subjects with 1-h plasma glucose levels. Diabetes Care 33, 411-413 (2010)

7. Coutinho, M., Gerstein, H. C., Wang, Y. \& Yusuf, S. The relationship between glucose and incident cardiovascular events. A metaregression analysis of published data from 20 studies of 95,783 individuals followed for 12.4 years. Diabetes Care 22, 233-240 (1999).

8. Chung, H. K. et al. Growth differentiation factor 15 is a myomitokine governing systemic energy homeostasis. J. Cell Biol. 216, 149-165 (2017).

9. Deleidi, M., Jaggle, M. \& Rubino, G. Immune aging, dysmetabolism, and inflammation in neurological diseases. Front. Neurosci. 9, 172 (2015).

10. Giubilato, S. et al. Expansion of CD4+CD28null T-lymphocytes in diabetic patients: exploring new pathogenetic mechanisms of increased cardiovascular risk in diabetes mellitus. Eur. Heart J. 32, 1214-1226 (2011).

11. Youn, J. C. et al. Immunosenescent CD8+ T cells and C-X-C chemokine receptor type 3 chemokines are increased in human hypertension. Hypertension 62, 126-133 (2013).

12. Weng, N. P., Akbar, A. N. \& Goronzy, J. CD28(-) T cells: their role in the ageassociated decline of immune function. Trends Immunol. 30, 306-312 (2009).

13. Focosi, D., Bestagno, M., Burrone, O. \& Petrini, M. CD57+ T lymphocytes and functional immune deficiency. J. Leukoc. Biol. 87, 107-116 (2010).

14. Vallejo, A. N., Brandes, J. C., Weyand, C. M. \& Goronzy, J. J. Modulation of CD28 expression: distinct regulatory pathways during activation and replicative senescence. J. Immunol. 162, 6572-6579 (1999).

15. Maeda, T. et al. Involvement of CD4+,CD57+ T cells in the disease activity of rheumatoid arthritis. Arthritis Rheum. 46, 379-384 (2002).

16. Le Priol, Y. et al. High cytotoxic and specific migratory potencies of senescent CD8+ CD57+ cells in HIV-infected and uninfected individuals. J. Immunol. 177, 5145-5154 (2006).

17. Palmer, B. E., Mack, D. G., Martin, A. K., Maier, L. A. \& Fontenot, A. P. CD57 expression correlates with alveolitis severity in subjects with beryllium-induced disease. J. Allergy Clin. Immunol. 120, 184-191 (2007).

18. Hoffmann, J. et al. High-throughput 13-parameter immunophenotyping identifies shifts in the circulating T-cell compartment following reperfusion in patients with acute myocardial infarction. PLOS ONE 7, e47155 (2012).

19. Brenchley, J. M. et al. Expression of CD57 defines replicative senescence and antigen-induced apoptotic death of CD8+ T cells. Blood 101, 2711-2720 (2003).

20. Palmer, B. E., Blyveis, N., Fontenot, A. P. \& Wilson, C. C. Functional and phenotypic characterization of CD57+CD4+ T cells and their association with HIV-1-induced T-cell dysfunction. J. Immunol. 175, 8415-8423 (2005).

21. Haffner, S. M. Pre-diabetes, insulin resistance, inflammation and CVD risk Diabetes Res Clin. Pract. 61, S9-S18 (2003).

22. Pascual, M., Gomez-Lechon, M. J., Castell, J. V. \& Jover, R. ATF5 is a highly abundant liver-enriched transcription factor that cooperates with constitutive androstane receptor in the transactivation of CYP2B6: implications in hepatic stress responses. Drug Metab. Dispos. 36, 1063-1072 (2008).

23. Luck, $H$. et al. Regulation of obesity-related insulin resistance with gut antiinflammatory agents. Cell Metab. 21, 527-542 (2015).

24. McLaughlin, T. et al. T-cell profile in adipose tissue is associated with insulin resistance and systemic inflammation in humans. Arterioscler. Thromb. Vasc. Biol. 34, 2637-2643 (2014).

25. Kaneto, H., Katakami, N., Matsuhisa, M. \& Matsuoka, T. A. Role of reactive oxygen species in the progression of type 2 diabetes and atherosclerosis. Mediat. Inflamm. 2010, 453892 (2010).

26. Buck, M. D., O'Sullivan, D. \& Pearce, E. L. T-cell metabolism drives immunity. J. Exp. Med. 212, 1345-1360 (2015). 
27. Fiorese, C. J. et al. The transcription factor ATF5 mediates a mammalian mitochondrial UPR. Curr. Biol. 26, 2037-2043 (2016).

28. Park, M. H. et al. Age-related inflammation and insulin resistance: a review of their intricate interdependency. Arch. Pharm. Res 37, 1507-1514 (2014).

29. Strioga, M., Pasukoniene, V. \& Characiejus, D. CD8+ CD28- and CD8+ CD57 $T$ cells and their role in health and disease. Immunology 134, 17-32 (2011).

30. Ortiz-Suarez, A. \& Miller, R. A. A subset of CD8 memory T cells from old mice have high levels of CD28 and produce IFN-gamma. Clin. Immunol. 104, 282-292 (2002)

31. Molofsky, A. B. et al. Innate lymphoid type 2 cells sustain visceral adipose tissue eosinophils and alternatively activated macrophages. J. Exp. Med. 210 535-549 (2013).

32. Shirakawa, $\mathrm{K}$. et al. Obesity accelerates $\mathrm{T}$ cell senescence in murine visceral adipose tissue. J. Clin. Invest 126, 4626-4639 (2016).

33. Byun, J. S. \& Yi, H. S. Hepatic immune microenvironment in alcoholic and nonalcoholic liver disease. Biomed. Res. Int. 2017, 6862439 (2017).

34. Grossmann, V. et al. Profile of the immune and inflammatory response in individuals with prediabetes and type 2 diabetes. Diabetes Care 38, 1356-1364 (2015).

35. Fabbrini, E. et al. Association between specific adipose tissue CD4+ T-cell populations and insulin resistance in obese individuals. Gastroenterology 145, 366-374 (2013). e361-363.

36. Nishimura, S. et al. CD8+ effector T cells contribute to macrophage recruitment and adipose tissue inflammation in obesity. Nat. Med. 15, 914-920 (2009).

37. Rocha, V. Z. et al. Interferon-gamma, a Th1 cytokine, regulates fat inflammation: a role for adaptive immunity in obesity. Circ. Res. 103, 467-476 (2008).

38. Winer, $\mathrm{S}$. et al. Normalization of obesity-associated insulin resistance through immunotherapy. Nat. Med. 15, 921-929 (2009).
39. Raphael, I., Nalawade, S., Eagar, T. N. \& Forsthuber, T. G. T cell subsets and their signature cytokines in autoimmune and inflammatory diseases. Cytokine 74, 5-17 (2015)

40. Akbar, A. N. \& Henson, S. M. Are senescence and exhaustion intertwined or unrelated processes that compromise immunity? Nat. Rev. Immunol. 11, 289-295 (2011)

41. Alber, H. F. et al. Neopterin, CD4+CD28- lymphocytes and the extent and severity of coronary artery disease. Int J. Cardiol. 135, 27-35 (2009).

42. Brugaletta, S. et al. Novel anti-inflammatory effect of statins: reduction of CD4 + CD28null T lymphocyte frequency in patients with unstable angina. Heart 92, 249-250 (2006).

43. Link, A. et al. Rosuvastatin induces apoptosis in CD4(+)CD28 (null) $T$ cells in patients with acute coronary syndromes. Clin. Res Cardiol. 100, 147-158 (2011).

44. Jeng, M. Y. et al. Metabolic reprogramming of human CD8(+) memory $T$ cells through loss of SIRT1. J. Exp. Med. 215, 51-62 (2018).

45. Previte, D. M. et al. Reactive oxygen species are required for driving efficient and sustained aerobic glycolysis during CD4+ T cell activation. PLOS ONE 12, e0175549 (2017).

46. Padgett, L. E., Broniowska, K. A., Hansen, P. A., Corbett, J. A. \& Tse, H. M. The role of reactive oxygen species and proinflammatory cytokines in type 1 diabetes pathogenesis. Ann. N. Y Acad. Sci. 1281, 16-35 (2013).

47. Yi, H. S. et al. Alcohol dehydrogenase III exacerbates liver fibrosis by enhancing stellate cell activation and suppressing natural killer cells in mice. Hepatology 60, 1044-1053 (2014).

48. Lee, Y. S. et al. Hepatic immunophenotyping for streptozotocin-induced hyperglycemia in mice. Sci. Rep. 6, 30656 (2016). 